\title{
Oxidation-state distribution of plutonium in surface and subsurface waters at Thule, northwest Greenland
}

\author{
C.A. McMahon ${ }^{\mathrm{a}}$, L. León Vintró ${ }^{\mathrm{a}}$, P.I. Mitchell ${ }^{\mathrm{a}, *}$, H. Dahlgaard ${ }^{\mathrm{b}}$ \\ ${ }^{a}$ Department of Experimental Physics, University College Dublin, Stillorgan Road, Belfield, Dublin 4, Ireland \\ ${ }^{\mathrm{b}}$ Riso National Laboratory, Roskilde, Denmark
}

\begin{abstract}
The speciation of plutonium in Arctic waters sampled on the northwest Greenland shelf in August 1997 is discussed in this paper. Specifically, we report the results of analyses carried out on seawater sampled (a) close to the Thule air base where, in 1968, a US military aircraft carrying four nuclear weapons crashed on sea ice, releasing kilogram quantities of plutonium to the snow pack and underlying seabed sediments, and (b) at a reference station (Upernavik) located $\sim 400 \mathrm{~km}$ to the south. The data show that most of the plutonium in the dissolved phase at Thule is in the form of $\mathrm{Pu}(\mathrm{V}, \mathrm{VI})$ (mean: $68 \pm 6 \% ; n=6$ ), with little if any distinction apparent between surface and bottom waters. Further, the oxidation state distribution at stations close to the accident site is similar to that measured at Upernavik, remote from this site. It is also similar to the distribution observed in shelf waters at midlatitudes, suggesting that the underlying processes controlling plutonium speciation are insensitive to temperature over the range $0-25^{\circ} \mathrm{C}$. Measurements using tangential-flow ultrafiltration indicate that virtually all of the plutonium (including the fraction in a reduced chemical form) is present as fully dissolved species. Most of this plutonium would seem to be of weapons fallout origin, as the mean ${ }^{238} \mathrm{Pu} /{ }^{239,240} \mathrm{Pu}$ activity ratio in the water column (dissolved phase $)$ at Thule $(0.06 \pm 0.02 ; n=10)$ is similar to the global fallout ratio at this latitude $(\approx 0.04)$. Thus, there is little evidence of weapons-grade plutonium in the water column at Thule at the present time. (C) 2000 Elsevier Science Ltd. All rights reserved.
\end{abstract}

\section{Introduction}

\subsection{Background}

For over two decades, considerable effort has been expended in attempts to develop a comprehensive understanding of the behaviour of plutonium in the marine environment. Much of the earlier work was conducted at mid-latitudes and, in particular, in

\footnotetext{
* Corresponding author. Tel.: + 353-1-706-2222; fax: + 3531-283-7275.

E-mail address: peter.mitchell@ucd.ie (P.I. Mitchell).
}

coastal areas where the levels of plutonium were known to be enhanced as a consequence of historic discharges or nuclear accidents, and at deep ocean sites where weapons-fallout plutonium was sometimes used as a marker for particle sedimentation. In recent years, the focus has shifted to more extreme environments as the need to develop realistic models for radiopollutant transport in vulnerable ecosystems (e.g., the Arctic shelf seas and the central Arctic Ocean) became important. All such models require as input reliable, site-specific, parameter values which, clearly, can only be obtained from appropriate field measurements. A key parameter is the sediment-water distribution coefficient $\left(K_{\mathrm{d}}\right)$ which, for plutonium, has been found to 

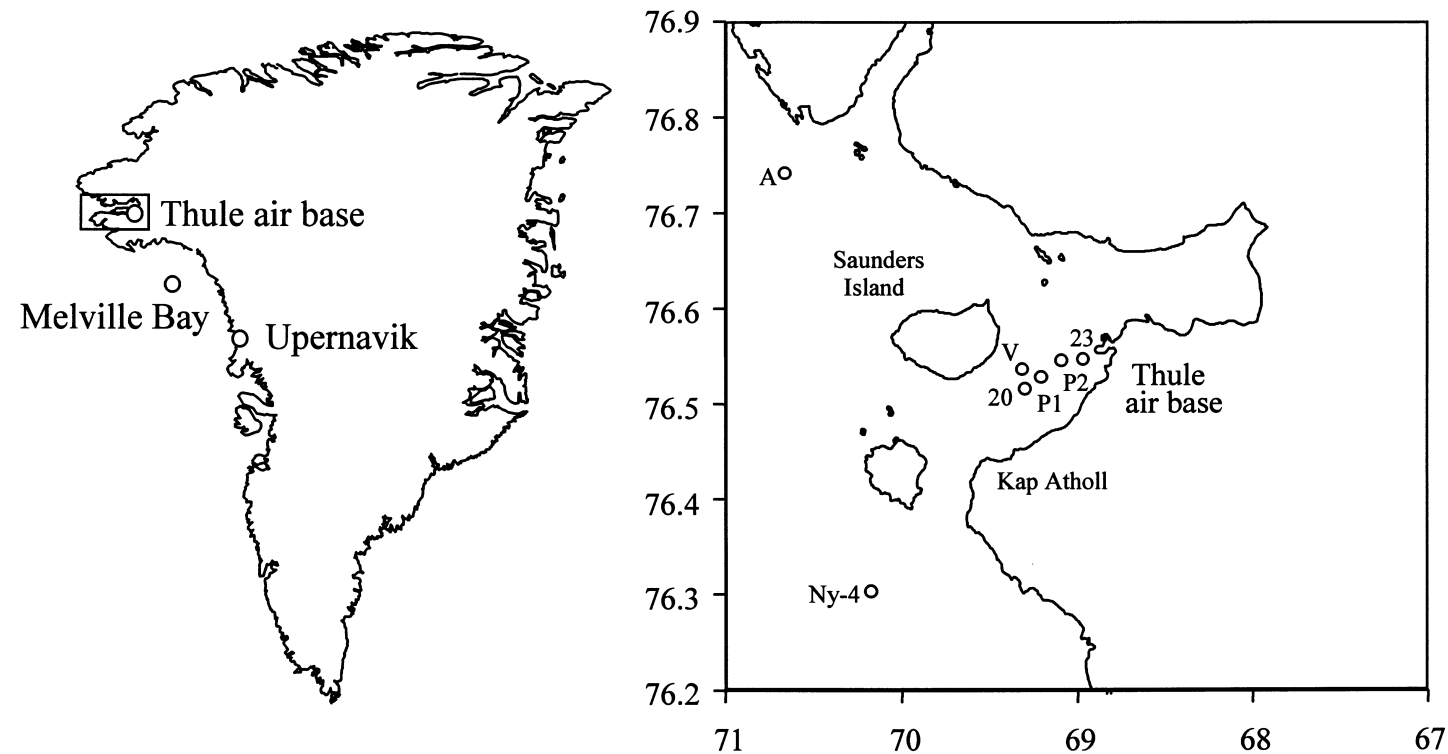

Fig. 1. Sampling stations during the Thule ' 97 expedition. Note: station V corresponds to the site of the 1968 accident.

be highly sensitive to the particular chemical form(s) in which it is present in the water column. Thus, knowledge of the plutonium species involved is essential to a proper understanding of its behaviour. In this paper we present for the first time data on the physico-chemical speciation of this element in an Arctic water column and compare these data with similar data from other studies conducted at more temperate latitudes.

\subsection{Plutonium seawater chemistry}

Plutonium in natural waters presents as a mixture of ionic, particulate, colloidal and pseudo-colloidal species, the relative proportions of which depend on factors such as chemical form upon input, seawater chemistry, concentration of dissolved organic carbon, suspended particulate loading, etc. The chemistry is complex, studies having shown that in aqueous solution plutonium can exist in at least four distinct oxidation states simultaneously (Polzer, 1971). In seawater, oxidation states IV and $\mathrm{V}$ have been shown to predominate as the reduced $\left(\mathrm{Pu}(\mathrm{OH})_{4}\right)$ and oxidised $\left(\mathrm{PuO}_{2}^{+}\right)$forms, respectively. Consequently, plutonium can be thought of as being present in two distinct forms: reduced plutonium, $\mathrm{Pu}(\mathrm{IV})$, which is highly particle-reactive and is thus quickly scavenged by particles, sediments and colloids; and oxidised plutonium, $\mathrm{Pu}(\mathrm{V})$, which is relatively soluble and can be transported over long distances within the dissolved phase.
These two forms of plutonium exhibit very different sediment-water distribution coefficients $\left(K_{\mathrm{d}}\right)$, with reduced plutonium possessing a $K_{\mathrm{d}}$ approximately two orders of magnitude higher than oxidised plutonium, i.e., $10^{6}$ compared to $10^{3}-10^{4}$ (Nelson and Lovett, 1978).

\subsection{The Thule accident site}

In January 1968, an American B-52 bomber carrying four plutonium-bearing weapons crashed on the sea ice in Bylot Sound (Greenland), $11 \mathrm{~km}$ west of the Thule Air Base. The aircraft and the chemical explosive component of all four weapons exploded on impact, causing the release of kilogram quantities of plutonium, in the form of insoluble plutonium oxide $\left(\mathrm{PuO}_{2}\right)$, to the snow pack and underlying seabed sediment (Langham, 1970; Risø, 1970; Aarkrog, 1971). Although it has been estimated that $\sim 90 \%$ of the plutonium was subsequently removed in the ensuing clean-up operation, residual contamination totalling an estimated $1 \mathrm{TBq}$ ${ }^{239} \mathrm{Pu}(\sim 0.5 \mathrm{~kg})$ is now known to cover a seabed area in the order of $1000 \mathrm{~km}^{2}$ (Aarkrog et al., 1984; Smith et al., 1994). Thule Air Base is located in Bylot Sound on the northwestern coast of Greenland. The area has an arctic climate, with a mean winter temperature of $-22^{\circ} \mathrm{C}$ and a mean summer temperature of $+4^{\circ} \mathrm{C}$. Mean annual precipitation is very low, at less than 100 mm (Hardy and Rivera, 1969). 
Table 1

${ }^{239,240} \mathrm{Pu}$ concentrations and ${ }^{238} \mathrm{Pu} /{ }^{239,240} \mathrm{Pu}$ activity ratios in filtered seawater sampled off the nothwest coast of Greenland in August 1997 (uncertainties are given to $\pm 1 \sigma$ )

\begin{tabular}{|c|c|c|c|c|}
\hline Location & Station depth (m) & Sampling depth (m) & ${ }^{239,240} \mathrm{Pu}\left(\mathrm{mBq} \mathrm{m}^{-3}\right)$ & ${ }^{238} \mathrm{Pu} /{ }^{239,240} \mathrm{Pu}$ activity ratio \\
\hline \multicolumn{5}{|l|}{ Thule } \\
\hline \multirow[t]{2}{*}{ Station Ny-4 $\left(76^{\circ} 18^{\prime} \mathrm{N}, 70^{\circ} 13^{\prime} \mathrm{W}\right)$} & 290 & 2 & $5.8 \pm 0.5$ & $0.04 \pm 0.01$ \\
\hline & & 280 & $10.8 \pm 0.5$ & $0.10 \pm 0.04$ \\
\hline Station A $\left(76^{\circ} 45^{\prime} \mathrm{N}, 70^{\circ} 42^{\prime} \mathrm{W}\right)$ & 167 & 2 & $6.8 \pm 0.4$ & $0.09 \pm 0.04$ \\
\hline Station $23\left(76^{\circ} 31^{\prime} \mathrm{N}, 69^{\circ} 08^{\prime} \mathrm{W}\right)$ & 207 & 2 & $4.9 \pm 0.3$ & $0.03 \pm 0.01$ \\
\hline \multirow[t]{3}{*}{ Station $\mathrm{V}\left(76^{\circ} 32^{\prime} \mathrm{N}, 69^{\circ} 18^{\prime} \mathrm{W}\right)$} & 187 & 2 & $6.6 \pm 0.3$ & $0.04 \pm 0.01$ \\
\hline & & 100 & $11.2 \pm 0.4$ & $0.05 \pm 0.01$ \\
\hline & & 177 & $17.6 \pm 1.0$ & $0.07 \pm 0.02$ \\
\hline Station $20\left(76^{\circ} 31^{\prime} \mathrm{N}, 69^{\circ} 17^{\prime} \mathrm{W}\right)$ & 233 & 2 & $9.3 \pm 0.6$ & $0.06 \pm 0.01$ \\
\hline Station P1 $\left(76^{\circ} 32^{\prime} \mathrm{N}, 69^{\circ} 05^{\prime} \mathrm{W}\right)$ & $200^{\mathrm{a}}$ & 2 & $3.3 \pm 0.2$ & $0.09 \pm 0.03$ \\
\hline Station P2 $\left(76^{\circ} 31^{\prime} \mathrm{N}, 69^{\circ} 19^{\prime} \mathrm{W}\right)$ & $225^{\mathrm{a}}$ & 2 & $3.2 \pm 0.4$ & $0.05 \pm 0.03$ \\
\hline \multicolumn{5}{|l|}{ Melville Bay } \\
\hline Station $2\left(75^{\circ} 00^{\prime} \mathrm{N}, 64^{\circ} 11^{\prime} \mathrm{W}\right)$ & $300^{\mathrm{a}}$ & 2 & $2.4 \pm 0.3$ & $<0.07$ \\
\hline \multicolumn{5}{|l|}{ Upernavik } \\
\hline Station $1\left(72^{\circ} 49^{\prime} \mathrm{N}, 56^{\circ} 12^{\prime} \mathrm{W}\right)$ & $50^{\mathrm{a}}$ & 2 & $7.5 \pm 0.4$ & $0.14 \pm 0.06$ \\
\hline \multicolumn{3}{|l|}{ Mean $(n=9)$ in surface water } & $5.5 \pm 2.3$ & $0.07 \pm 0.04$ \\
\hline
\end{tabular}

${ }^{\text {a }}$ Estimated from bathymetric plots.

\section{Methodology}

In the course of a collaborative research expedition to northwest Greenland and the Thule accident site in August-September 1997, a number $(n=12)$ of surface and subsurface water samples (100-200 1 each) were collected with a view to examining the physico-chemical speciation of plutonium in the water column (see Fig. 1). Upon collection, the samples were promptly filtered through membrane filters $(0.45 \mu \mathrm{m})$ and the filtered water analysed either for total plutonium content by the standard technique of coprecipitation with $\mathrm{Fe}(\mathrm{OH})_{3}$ (Wong, 1971), or for reduced and oxidised plutonium following separation using the so-called limited iron technique (Harvey et al., 1991; Blowers, pers. comm.). The latter is based on the sequential coprecipitation of the reduced plutonium species with small amounts of ferric hydroxide and relies on the fact that very small quantities of iron carrier $\left(\mathrm{Fe}^{3+}\right)$ quantitatively coprecipitate the reduced plutonium species, $\mathrm{Pu}(\mathrm{III}, \mathrm{IV})$, but not the oxidised species, $\mathrm{Pu}(\mathrm{V}, \mathrm{VI})$ (Lovett et al., 1990). Note that the limited iron technique does not discriminate between $\mathrm{Pu}(\mathrm{III})$ and $\mathrm{Pu}(\mathrm{IV})$, nor between $\mathrm{Pu}(\mathrm{V})$ and $\mathrm{Pu}(\mathrm{VI})$. The addition of two distinct isotopic monitors (e.g., ${ }^{236} \mathrm{Pu}(\mathrm{VI})$ in an oxidised form and ${ }^{242} \mathrm{Pu}(\mathrm{IV})$ in a reduced form) enabled corrections to be made for any change of oxidation state during the preconcentration and separation steps, by quantification of the extent of crossover of the ${ }^{236} \mathrm{Pu}(\mathrm{VI})$ monitor and the ${ }^{242} \mathrm{Pu}(\mathrm{IV})$ moni- tor into the reduced and oxidised fractions, respectively (Vives i Batlle, 1993).

Briefly, the two monitors, ${ }^{242} \mathrm{Pu}(\mathrm{IV})$ and ${ }^{236} \mathrm{Pu}(\mathrm{VI})$, were added to the filtered seawater which was then made $0.3 \mathrm{M}$ with respect to $\mathrm{HCl}$. A small amount of $\mathrm{Fe}^{3+}(0.1 \mathrm{mg}$ per litre of sample) was added. After thoroughly mixing for $15 \mathrm{~min}$, the reduced plutonium fraction was coprecipitated with ferric hydroxide following neutralisation with ammonia (to $\mathrm{pH}>9$ ) and the sample left to stand for a further $15 \mathrm{~min}$. The precipitate was then collected by filtration through a 0.45 $\mu \mathrm{m}$ membrane filter and retained for analysis of the reduced plutonium fraction. At this point the oxidised plutonium fraction in the filtrate was reduced under acid conditions by the addition of sodium sulphite $(2 \mathrm{~g}$ per 1 of sample) and ferrous ammonium sulphate (3 mg $\mathrm{Fe}^{2+}$ per 1 of sample). The coprecipitation process was repeated and this second ferric hydroxide precipitate retained for analysis of the oxidised plutonium fraction. Tracer cross over was monitored carefully throughout and was found to be less than $6 \%$ in all cases.

To determine whether any plutonium was present in colloidal form, large volumes ( 500 1) of seawater were collected at two stations (Stations A and P2) and filtered in situ through $0.45 \mu \mathrm{m}$ filters prior to (tangential flow) ultrafiltration using 1 and $10 \mathrm{kDa}$ polysulphone membranes. The (total) plutonium content in both the permeate and retentate fractions was then determined as described above. 
Table 2

${ }^{239,240} \mathrm{Pu}$ concentrations, percentage of ${ }^{239,240} \mathrm{Pu}$ in particulate form and ${ }^{238} \mathrm{Pu} /{ }^{239,240} \mathrm{Pu}$ activity ratios in suspended particulate matter sampled off the northwest coast of Greenland in August 1997 (uncertainties are given to $\pm 1 \sigma$ )

\begin{tabular}{|c|c|c|c|c|}
\hline Location & Sampling depth (m) & ${ }^{239,240} \mathrm{Pu}\left(\mathrm{mBq} \mathrm{m}{ }^{-3}\right)$ & ${ }^{239,240} \mathrm{Pu} \%$ particulate & ${ }^{238} \mathrm{Pu} /{ }^{239,240} \mathrm{Pu}$ \\
\hline Station A & 2 & $0.47 \pm 0.1$ & 7 & $<0.07$ \\
\hline \multirow[t]{2}{*}{ Station V } & 100 & $4.9 \pm 0.5$ & 30 & $<0.07$ \\
\hline & 177 & $12.6 \pm 0.7$ & 42 & $0.006 \pm 0.003$ \\
\hline Station P2 & 2 & $0.35 \pm 0.1$ & 10 & $<0 . \overline{07}$ \\
\hline
\end{tabular}

In all cases, following further purification using routine radiochemical separation techniques based on selective sorption on ion-exchange resins and electrodeposition of the purified plutonium onto stainless-steel discs, the concentration of ${ }^{239,240} \mathrm{Pu}$ (and ${ }^{238} \mathrm{Pu}$ where possible) in each fraction was determined by high-resolution alpha spectrometry using $450 \mathrm{~mm}^{2}$ passivated ion-implanted silicon detectors. Typically, radiochemical yields were in the range $60-70 \%$.

\section{Results and discussion}

\subsection{Plutonium concentrations}

Overall, ${ }^{239,240} \mathrm{Pu}$ concentrations in filtered seawater from the coastal shelf of northwest Greenland were very low (see Table 1), with surface concentrations showing a mean value of $5.5 \pm 2.3 \mathrm{mBq} \mathrm{m}^{-3}(n=9)$. This is consistent with concentrations recorded in surface waters in other areas of the Arctic Ocean in recent years (e.g., Holm et al., 1996; Mitchell et al., 1998; León Vintró et al., submitted for publication). Noticeably higher concentrations (factor of $\approx 2-3$ ) were found in near-bottom waters. In previous studies

Table 3

Oxidation-state distribution of ${ }^{239,240} \mathrm{Pu}$ in filtered seawater sampled off the northwest coast of Greenland in August 1997 (uncertainties are given to $\pm 1 \sigma$ )

\begin{tabular}{lrl}
\hline Location & Station depth $(\mathrm{m})$ & ${ }^{239,240} \mathrm{Pu}(\mathrm{V}, \mathrm{VI})(\%)$ \\
\hline Thule & & \\
Station Ny-4 & 2 & $75 \pm 8$ \\
& 280 & $68 \pm 5$ \\
Station V & 2 & $67 \pm 4$ \\
& 100 & $65 \pm 4$ \\
Station 20 & 177 & $59 \pm 3$ \\
Upernavik & 2 & $76 \pm 7$ \\
Station 1 & 2 & $77 \pm 9$ \\
Mean $(n=7)$ & & $70 \pm 7$ \\
Range & & $59-77$ \\
\hline
\end{tabular}

undertaken at Thule higher plutonium concentrations were observed in near-bottom water samples (unfiltered) which were attributed to the disturbance of seabed sediment during sampling (Aarkrog, 1977; Aarkrog et al., 1984). Our observations show that a considerably higher proportion (factor of $\approx 4$ ) of the total plutonium present in near-bottom water is attached to suspended particulate matter (Table 2). As higher concentrations are also evident in the filtered fraction at these depths, it seems to us that a more plausible explanation for the elevated levels lies in a combination of vertical scavenging and physical resuspension of contaminated seabed sediment.

\subsection{Plutonium oxidation-state distribution}

Our data (Table 3) show that most of the plutonium in the dissolved phase at all four Greenland stations is in an oxidised form, i.e., $\mathrm{Pu}(\mathrm{V}, \mathrm{VI})$, highlighting the well-oxygenated character of these cold shelf waters. Further, there appears to be no difference between the oxidation state distribution measured at stations close to the Thule accident site and that at a reference station remote from this site (i.e., Upernavik). Overall, the percentage of oxidised ${ }^{239,240} \mathrm{Pu}$ in surface waters near Thule is similar to that observed at lower latitudes (see Table 4), suggesting that the underlying processes controlling plutonium speciation are, to first order, insensitive to temperature over the range 0 $25^{\circ} \mathrm{C}$. Unfortunately, there appears to be no published data on the oxidation-state distribution of plutonium in Arctic waters with which we can compare our results, with the exception of a single measurement by Pentreath et al. (1986), who reported a value of $55 \%$ for oxidised plutonium at an unspecified location in the Arctic (understood to be somewhere within the Norwegian Sea).

\subsection{Analysis for plutonium in colloidal form}

The possibility that some of the plutonium in Thule waters was present in colloidal form was examined in two separate ultrafiltration experiments (Table 5). Analysis of the results revealed that retention of plutonium by 1 and $10 \mathrm{kDa}$ ultrafilters was negligible, indi- 
Table 4

Oxidation-state distribution of ${ }^{239,240} \mathrm{Pu}$ in filtered seawater from other shallow coastal waters

\begin{tabular}{lll}
\hline Location & ${ }^{239,240} \mathrm{Pu}(\mathrm{V}, \mathrm{VI})(\%)$ & Reference \\
\hline Irish Sea & $70-89$ & Nelson and Lovett, 1978 \\
Irish Sea & $80-94$ & Mitchell et al., 1991, 1995 \\
English Channel & $76-79$ & Boust et al., 1996 \\
Western Mediterranean Sea & $63-71$ & Mitchell et al., 1995 \\
Mediterranean Sea (Palomares zone) & 68 & Mitchell et al., 1995 \\
Enewetok and Bikini Atolls & 92 & Noshkin and Wong, 1981 \\
\hline
\end{tabular}

cating that there was little, if any, plutonium associated with colloidal species in these waters. This observation is similar to results reported recently for more temperate environments where virtually all of the plutonium, including the fraction in a reduced chemical form, was found to be present as fully dissolved species (Downes, 1999).

\section{4. $\left.{ }^{238} \mathrm{Pu}\right|^{239,240} \mathrm{Pu}$ activity ratios}

Measurement of the ${ }^{238} \mathrm{Pu} /{ }^{239,240} \mathrm{Pu}$ ratio in the water column (dissolved phase) at Thule yielded a mean value of $0.06 \pm 0.02(n=10)$ which, being similar to the global fallout ratio at this latitude of $\approx 0.04$, suggests that there is virtually no weapons-grade plutonium in the Thule water column at the present time. This is in sharp contrast to the seabed sediments, which show considerable inhomogeneities in their plutonium content, with ratios in some samples as low as 0.01-0.02, characteristic of weapons-grade plutonium (Aarkrog et al., 1987; Holm et al., 1988; Smith et al., 1994; Mitchell et al., 1997; Dahlgaard et al., 1998). Statistically there was no difference in the ratios recorded in surface and subsurface waters, suggesting that even in near-bottom waters (dissolved phase) glo-

Table 5

Concentrations of ${ }^{239,240} \mathrm{Pu}$ in the permeate and retentate fractions upon ultrafiltration through membranes with nominal molecular weight cut-offs of 10 and $1 \mathrm{kDa}$ (uncertainties are given to $\pm 1 \sigma$ )

\begin{tabular}{lll}
\hline Location & Size fraction $(x)$ & ${ }^{239,240} \mathrm{Pu}\left(\mathrm{mBq} \mathrm{m}^{-3}\right)$ \\
\hline Station A & $x<0.45 \mu \mathrm{m}$ & $6.8 \pm 0.4$ \\
& $10 \mathrm{kDa}<x<0.45 \mu \mathrm{m}$ & $5.3 \pm 0.7$ \\
& $x<10 \mathrm{kDa}$ & $6.2 \pm 0.9$ \\
& $1 \mathrm{kDa}<x<0.45 \mu \mathrm{m}$ & $4.2 \pm 0.8$ \\
& $x<1 \mathrm{kDa}$ & $5.7 \pm 0.9$ \\
Station P2 & $x<0.45 \mu \mathrm{m}$ & $3.2 \pm 0.4$ \\
& $10 \mathrm{kDa}<x<0.45 \mu \mathrm{m}$ & $2.3 \pm 0.2$ \\
& $x<10 \mathrm{kDa}$ & $2.9 \pm 0.3$ \\
& $1 \mathrm{kDa}<x<0.45 \mu \mathrm{m}$ & $2.7 \pm 0.3$ \\
& $x<1 \mathrm{kDa}$ & $2.9 \pm 0.3$ \\
\hline
\end{tabular}

bal fallout ${ }^{239,240} \mathrm{Pu}$ now predominates. This is consistent with observations made in the early 1990s in the vicinity of the coastal village of Palomares (Spain), where a similar accident involving nuclear weapons occurred in January 1966 (Mitchell et al., 1995).

In the case of suspended particulate, the only sample in which it proved possible to determine the ${ }^{238} \mathrm{Pu} /{ }^{239,240} \mathrm{Pu}$ activity ratio with reasonable precision gave a value of $0.006 \pm 0.003$, consistent with the isotopic signature of the plutonium released in the Thule accident. This sample was taken at the actual accident site (Station V), some few metres above the seabed, and the very low ratio more than likely reflects the presence of some accident-contaminated fine sediment in the water column following resuspension during the severe storm which occurred two days prior to sampling.

\section{Conclusions}

Our key conclusions are these:

1. At the present time, the oxidation-state distribution of plutonium in the shallow waters of the northwest Greenland continental shelf is similar to that observed in shelf waters at intermediate latitudes (e.g., Palomares offshore zone, Irish Sea).

2. None of the plutonium in the traditionally-defined $(<0.45 \mu \mathrm{m})$ dissolved phase appears to be in colloidal form.

3. In surface waters, less than $10 \%$ of the plutonium inventory is associated with suspended matter. This percentage increases to almost $40 \%$ near the seabed.

4. Examination of the ${ }^{238} \mathrm{Pu} /{ }^{239,240} \mathrm{Pu}$ ratio in surface and near-bottom waters indicates that essentially all of the plutonium in the dissolved phase in the Thule water column at the present time is of global fallout origin.

\section{Acknowledgements}

This study was made possible by the generous finan- 
cial support provided under the European Commission's Nuclear Fission Safety Programme, 1995-1999 (Contract No. F14P-CT95-0035). It could not have taken place without the cooperation of the Arctic Monitoring and Assessment Programme (AMAP) who provided the marine platform. We are indebted to them and to the captain and crew of the Greenland Home Rule Fisheries Research Vessel F.S. Adolf Jensen for their support while on station.

\section{References}

Aarkrog, A., 1971. Radioecological investigations of plutonium in an Arctic marine environment. Health Phys. 20, $31-47$.

Aarkrog, A., 1977. Environmental behaviour of plutonium accidentally released at Thule, Greenland. Health Phys. 32, 271-284.

Aarkrog, A., Boelskifte, S., Dahlgaard, H., Duniec, S., Holm, E., Smith, J.N., 1987. Studies of transuranics in an Arctic marine environment. J. Radioanal. Nucl. Chem. Art. 115 (1), 39-50.

Aarkrog, A., Dahlgaard, H., Nilsson, K., Holm, E., 1984. Further studies of plutonium and americium at Thule, Greenland. Health Phys. 46 (1), 29-44.

Blowers, P., personal communication.

Boust, D., Mitchell, P.I., Garcia, K., Condren, O.M., León Vintró, L., Leclerc, G., 1996. A comparative study of the speciation and behaviour of plutonium in the marine environment of two reprocessing plants. Radiochim. Acta 74, 203-210.

Dahlgaard, H., Chen, Q.J., Stürup, S., Eriksson, M., Nielsen, S.P., Aarkrog, A., 1998. Plutonium isotope ratios in environmental samples from Thule (Greenland) and the Techa river (Russia) measured by ICPMS and $\alpha$-spectrometry. In: Proc. Int. Symposium on Marine Pollution, Monaco, 5-9 October 1998. IAEA.

Downes, A.B., 1999. Speciation and colloidal association of plutonium, americium and polonium in marine environments. Ph.D. thesis, University College Dublin, National University of Ireland, Dublin, $124 \mathrm{pp}$.

Hardy, E.P., Rivera, J. 1969. Fallout program quarterly summary report, USAEC Report HASL-210, July 1969.

Harvey, B.R., Leonard, K.S., Lovett, M.B., 1991. Some experiences with chemical and physical techniques for the separation of different species of man-made radionuclides in environmental waters. In: García-León, M., Madurga, G. (Eds.), Proc. Low-level Measurements of Man-made Radionuclides in the Environment, Second International Summer School, La Rábida, Spain, 25 June-6 July 1990, pp. 263-292.

Holm, E., Gastaud, J., Oregioni, B., Aarkrog, A., Dahlgaard, H., Smith, J.N., 1988. Chemical partitioning of plutonium and americium in sediments from the Thule region (Greenland). In: Guary, J.C., Guegueniat, P., Pentreath, R.J. (Eds.), Radionuclides: A Tool for Oceanography. Elsevier Applied Science, pp. 351-361.

Holm, E., Roos, P., Josefsson, D., Persson, B., 1996. Radioactivity from the north pole to the Antarctic. In:
Guéguéniat, P., Germain, P., Métivier, H. (Eds.), Radionuclides in the Oceans: Inputs and Inventories. Les Éditions de Physique, pp. 59-74.

Langham, W.H., 1970. Technical and laboratory support. USAF Nucl. Safety 65, 36-41.

León Vintró, L., McMahon, C.A., Mitchell, P.I., Josefsson, D., Holm, E. and Roos, P. Transport of plutonium in surface and subsurface waters from the Laptev Sea to the north pole via the Lomonosov Ridge. In: Proc. 4th Int. Conference on Environmental Radioactivity in the Arctic, Edinburgh, Scotland, 20-23 September, 1999, submitted for publication.

Lovett, M.B., Boggis, S.J., Blowers, P., 1990. The Determination of Alpha-Emitting Nuclides of Plutonium, Americium and Curium in Environmental Materials. 1. Seawater. Ministry of Agriculture Fisheries and Food Directorate of Fisheries Research, Lowestoft $36 \mathrm{pp}$.

Mitchell, P.I., León Vintró, L., Dahlgaard, H., Gascó, C., Sánchez-Cabeza, J.A., 1997. Perturbation in the ${ }^{240} \mathrm{Pu} /{ }^{239} \mathrm{Pu}$ global fallout ratio in local sediments following the nuclear accidents at Thule (Greenland) and Palomares (Spain). Sci. Total Environ. 202, 147-153.

Mitchell, P.I., McMahon, C.A., León Vintró, L., Ryan, R.W., 1998. Plutonium in Arctic surface and subsurface waters at the St. Anna and Voronin Troughs. Rad. Prot. Dosim. 75 (1/4), 247-252.

Mitchell, P.I., Vives i Batlle, J., Ryan, T.P., Schell, W.R., Sánchez-Cabeza, J.A., Vidal-Quadras, A., 1991. Studies on the speciation of plutonium and americium in the western Irish Sea. In: Kershaw, P.J., Woodhead, D.S. (Eds.), Radionuclides in the Study of Marine Processes. Elsevier Applied Science, London, pp. 37-51.

Mitchell, P.I., Vives i Batlle, J., Downes, A.B., Condren, O.M., León Vintró, L., Sanchez-Cabeza, J.A., 1995. Recent observations on the physico-chemical speciation of plutonium in the Irish Sea and the Western Mediterranean. Appl. Radiat. Isot. 46 (11), 1175-1190.

Nelson, D.M., Lovett, M.B., 1978. Oxidation state of plutonium in the Irish Sea. Nature 276, 599-601.

Noshkin, V.E., Wong, K.M., 1981. Plutonium mobilization from sedimentary sources to solution in the marine environment. In: Proc. Marine Radioecology, 3rd Nuclear Energy Agency Seminar, Paris, 1979, pp. 165-178.

Pentreath, R.J., Harvey, B.R., Lovett, M.B., 1986. Chemical speciation of transuranium nuclides discharged into the marine environment. In: Bulman, R.A., Cooper, J.R. (Eds.), Speciation of Fission and Activation Products in the Environment. Elsevier Applied Science Publishers, London, pp. 312-325.

Polzer, W.L., 1971. Solubility of Plutonium in soil/water environments, a report prepared by USAEC. Report No. HASL-83401.

Risø, 1970. Project crested ice: a joint Danish-American report on the crash near Thule air base on 21 January 1968 of a B-52 bomber carrying nuclear weapons, Roskilde, Denmark.

Smith, J.N., Ellis, K.M., Aarkrog, A., Dahlgaard, H., Holm, E., 1994. Sediment mixing and burial of the ${ }^{239,240} \mathrm{Pu}$ pulse from the 1968 Thule, Greenland nuclear weapons accident. J. Environ. Radioactivity 25, 135-159.

Vives i Batlle, J., 1993. Speciation and bioavailabilty of pluto- 
nium and americium in the Irish Sea and other marine ecosystems. Ph.D. thesis, University College Dublin, National University of Ireland, Dublin, 347 pp.
Wong, K.M., 1971. Radiochemical determination of plutonium in seawater, sediments and marine organisms. Anal. Chim. Acta 56, 355-364. 